\title{
Konsepti viljelytoimen tulevaisuuden tiedonhallinnasta
}

\author{
Jere Kaivosoja $^{1)}$, Raimo Linkolehto ${ }^{1)}$, Frederick Teye ${ }^{1)}$ ja Raimo Nikkilä ${ }^{2)}$ \\ ${ }^{1)}$ MTT, Vakolantie 55,03400 Vihti, jere.kaivosoja@mtt.fi \\ ${ }^{2)}$ Aalto-yliopisto, Otaniementie 17, PL 15500,00076 Aalto,rnikkila@cc.hut.fi
}

\section{Tiivistelmä}

Tieto- ja viestintäteknologioiden hyödyntäminen on osoittautunut hyväksi keinoksi saavuttaa peltoviljelylle asetettuja kehitystavoitteita. Siinä keskeisessä roolissa ovat maatilan tiedonhallintajärjestelmät (FMIS), päätöksenteon avusteisuus, sekä täsmäviljelyn vaatima infrastruktuuri. Nykyään maatilan tiedonhallintajärjestelmä nähdään koostuvan useista eri osioista, joista osa on kokonaan ulkopuolisten palveluntarjoajien toteuttamia. Nämä eri osiot muodostavat puumaisen hierarkisen rakenteen. Tätä rakennetta on yleisellä tasolla tutkittu, mutta käytännön toteutukset ovat vielä puuttuneet. Tässä tutkimuksessa esitetään esimerkinomaisesti tulevaisuuden maatilan web-pohjaista tiedonhallintaa yksittäisen viljelyprosessin näkökulmasta. Loimme vaiheittain toimivat prototyypit tulevaisuuden viljelytoimista. Ensimmäiseksi muodostimme yhtenäisen kokonaisuuden perustuen kaikkiin tyypillisiin peltoviljelytoimenpiteisiin ja niiden vaatimiin pääprosesseihin. Tämän jälkeen suunnittelimme mahdollisimman haasteelliset mutta realistiset tulevaisuuden viljelytoimia tukevat prosessiketjut, joiden perusteella rakensimme prototyypin lisälannoituksen sekä kasvinsuojeluruiskutuksen toiminnallisen suunnittelun, toteutuksen sekä arvioinnin osalta. Prototyyppi sisälsi seuraavat vaiheet: ensin alueellisesti vaihteleva työtehtävä suunnitellaan käyttäen hyväksi peltolohkon paikkakohtaisia historiatietoja ja kasvukauden aikaisia tutkimustuloksia. Suunniteltu työtehtävä lähetetään palveluntarjoajalle, joka automaattisesti tarkistaa työtehtävän määräystenmukaisuuden ja huomauttaa mahdollisista poikkeamista. Tämän jälkeen hyväksytty työtehtävä ladataan työkoneyhdistelmän käytettäväksi. Työ voi alkaa, kun palvelimelta saatu säätieto on sopiva. Mikäli työ joudutaan olosuhteiden muutoksen takia keskeyttämään, keskeytynyt työ lähetetään palvelimelle. Uusi työtehtävä lasketaan muuttuneiden säätöarvojen ja jo toteutuneen työn perusteella. Työkone jatkaa työtään uusien säätöarvojen mukaan. Työn loputtua kerätty data lähetetään palvelimelle, jossa työstä lasketaan tarkat toteutumakartat. Toteutuma hyväksytetään vielä määräystenmukaisuuden tarkistavalla palveluntarjoajalla. Hyväksytty työ siirtyy lohkokirjanpitoon ja antaa tulevaisuudessa tarkkaa ja tärkeää tietoa viljelyprosessin onnistumisesta. Esitelty konsepti osoittaa, että web-pohjaisella puurakenteisella arkkitehtuurilla voidaan toteuttaa monipuolisia tulevaisuuden vaatimukset täyttäviä viljelytoimia. Näin mahdollistetaan useiden eri palveluntarjoajien hyödyntäminen samalla keventäen viljelijän työtaakkaa. Suunnitellun ja toteutuneen työn oikeellisuus saadaan osoitettua jäljitettävyyttä ja läpinäkyvyyttä varten. Parhaimmillaan aineistojen monipuolinen saatavuus ja rajapintojen yhtenevyys mahdollistavat tehokkaamman ja kokonaan uudenlaisen tietämyksentuottamisen koko viljelyprosessissa.

Asiasanat: FMIS, tiedonhallinta, GML, lisälannoitus, kasvinsuojeluruiskutus 


\section{Johdanto}

Nykypäivän peltoviljely kohtaa monenlaisia haasteita. Tuotantokustannuksia pitäisi saada laskettua, sekä sadot ja niiden laadut pitäisi maksimoida samalla minimoiden ympäristöpäästöt. Tieto- ja viestintäteknologioiden hyödyntäminen on osoittautunut hyväksi keinoksi saavuttaa peltoviljelylle asetettuja tavoitteita (Pesonen ym. 2011). Keskeisessä roolissa ovat maatilan tiedonhallintajärjestelmät (FMIS), päätöksenteon avusteisuus, sekä täsmäviljelyn vaatima infrastruktuuri. On olemassa paljon yksittäisiä näitä tarkoituksia palvelevia sovelluksia tai sovelluskokonaisuuksia, mutta niiden tuottamien aineistojen hyödyntäminen koko viljelyprosessissa on osoittautunut haasteelliseksi. Lisäksi koko viljelyprosessin kattaminen yhden palveluntarjoajan toimesta on havaittu epärealistiseksi. Nykyään maatilan tiedonhallintajärjestelmät nähdään yhtenä järjestelmänä muiden joukossa, ei niinkään yhtenä massiivisena kokonaisuutena (Nikkilä ym. 2010). Webpohjaisuuden on katsottu vastaavan parhaiten asetettuihin vaatimuksiin. Eurooppalaisessa yhteistyössä toteutetun Future Farm projektin johtopäätöksissä (Blackmore ja Apostolidi, 2011) FMIS-rakenne määriteltiin seuraavasti: Maatilan tiedonhallintajärjestelmä koostuu kokoelmasta eri sovelluksia, jotka riippuvat toisistaan. Sovellukset muodostavat puumaisen hierarkisen rakenteen, jossa toisistaan riippumattomat elementit muodostavat puun lehdet. Näitä elementtejä hyödyntävät sovellukset ovat solmuja, jotka vuorostaan toimivat seuraavien sovellusten lehtinä. Järjestelmän lopputuotteen tuottava sovellus toimii juurena. Puun tarkempi rakenne riippuu täysin käytettävistä sovelluksista ja sovelluskehityksestä. Eri sovellukset verkottuvat keskenään ja raja FMIS-järjestelmän ja ulkopuolisen palvelun välillä on häilyvä. Tämän geneerisyyden johdosta eri sovellusten rajapinnat täytyy olla tarkoin määriteltyjä, avoimia, joustavia sekä harmonisoituja. Wiebensohn ym. (2011) määrittivät sopivat avoimet tiedonsiirtoformaatit eri palveluiden välille: paikkatiedot GML:ssä (geography markup language), sekä maatalouden attribuuttitiedot agroXML:ssä.

Esitelty tiedonhallintajärjestelmä jää melko abstraktille tasolle. Tarvitaan koemuotoisia konkreettisia sovellusesimerkkejä, kuinka kyseisen mallin mukaan tulevaisuuden viljelytoimen tiedonhallinta toteutettaisiin. Tässä tutkimuksessa loimme vaiheittain toimivat prototyypit tulevaisuuden viljelytoimista, jotka samalla haastoivat monipuolisesti tarvittavan tiedonhallintainfrastruktuurin. Tutkimuksessa keskityimme työtehtävän toiminnalliseen suunnitteluun, toteutukseen ja arviointiin lisälannoituksen sekä kasvinsuojeluruiskutuksen osalta, mutta sama tiedonhallintamalli koskee peltoviljelyä kokonaisuudessaan.

\section{Aineisto ja menetelmät}

Sørensen ym. (2009) muodostivat tietovirtakaaviot tulevaisuuden eri viljelytoimille ja niihin liittyville prosesseille. Tietovirtakaavioista valitsimme tarkasteluumme kaksi haasteellisinta viljelytoimea eli kasvinsuojeluruiskutuksen sekä lisälannoituksen. Näiden viljelytoimien prosesseista muodostimme yhteisen pääprosessikaavion (kuva 2). Jonka tarkoituksena oli osoittaa, mitä erityyppisiä prosesseja viljelytoimeen voi liittyä. Tämän jälkeen testasimme kaavion kattavuuden lopuilla tavanomaisilla peltotoimilla, eli muokkaustyöllä, kylvöllä, kastelulla sekä puinnilla. 


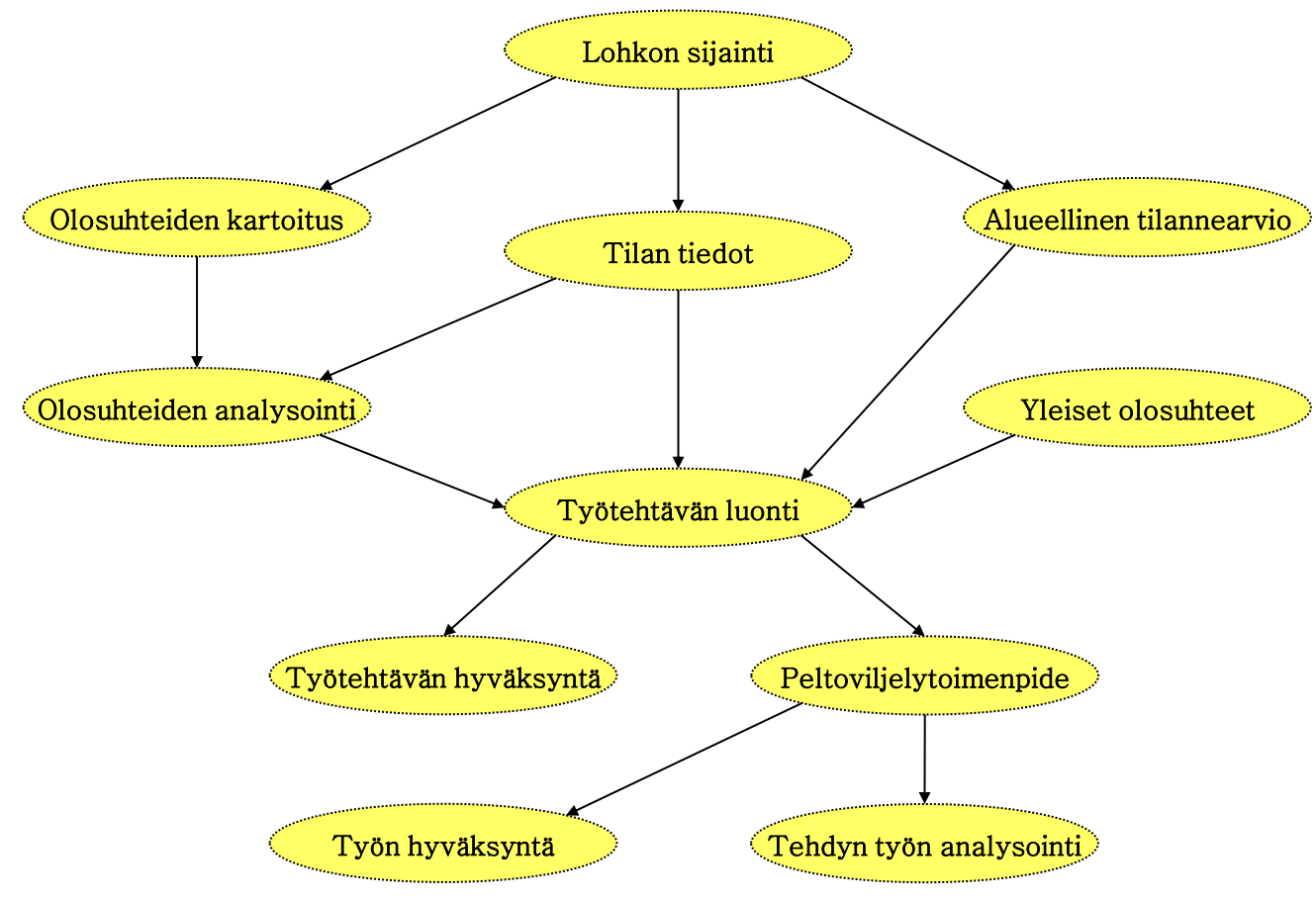

Kuva 2. Viljelytoimen suunnitteluun, toteutukseen ja arviointiin liittyvät pääprosessit.

Kaikki tyypilliset viljelytoimet ja niiden vaatimat pääprosessit seuraavat yllä olevaa kaaviota (kuva 2.). Viljelytoimen toiminnallisen suunnittelun lähtökohtana on yhtenäinen käsitys käsiteltävän peltolohkon sijainnista, koosta ja ulottuvuuksista. Ensimmäiseksi aloitetaan työtehtävän suunnittelu. Tähän voidaan tarvita eritasoista tietoa tilan lohkokirjanpidosta, pellon havaituista olosuhteista, alueellisia tilannearvioita, sekä yleisempiä lohkon sijaintiin liittyviä tilapäisiä tai pysyviä tietoja. Luotu työtehtävä hyväksytään, jonka jälkeen itse peltotyö suoritetaan. Tämä työ taltioidaan ja hyväksytään, sekä lopuksi analysoidaan koko viljelyprosessin näkökulmasta.

Tämän jälkeen yhdessä eurooppalaisen asiantuntijaryhmän kanssa keräsimme uusia mahdollisia innovaatioita sekä jo toteutettuja suljettuja viljelyn kokonaisprosessia palvelevia palveluita. Tähän pohjaan perustuen kokosimme futuristisen Tulokset-kappaleessa esiteltävän geneerisen prototyypin, joka kattaa lisälannoituksen sekä kasvinsuojeluruiskutuksen toiminnallisen suunnittelun, toteutuksen sekä arvioinnin tiedonhallinnan näkökulmasta.

\section{Tulokset}

Käsiteltävän peltolohkon rajat saadaan viranomaisen tarjoaman kyselypalvelun WFS (web feature service) rajapinnan kautta käyttöön. Näin varmistetaan lähtöaineiston määräystenmukaisuus sekä yhtenevyys. Olosuhteiden kartoitus toteutetaan kahdella eri tavalla: ilmakuvauksella sekä kasvustonäytteillä. Ilmakuvaus suoritetaan miehittämättömällä lennokilla ja lennot suorittaa lennokkikuvaukseen erikoistunut palveluntarjoaja. Tämän jälkeen kuvankäsittelyyn erikoistunut palveluntarjoaja lataa raakakuvat ja mosaikoi eri sävykanavat yhtenäisiksi kuviksi. Mosaikoidut kuva-aineisto luokitellaan suunniteltavan viljelytoimen näkökulmasta hyödyntäen pellolta tai lähialueilta otettuja kasvustonäytteitä, sekä peltolohkon paikkakohtaisia historiatietoja, sekä kasvukauden aikana tehtyjä havaintoja. Nämä lohkon historiatiedot saadaan maatilan tiedonhallintajärjestelmästä attribuuttitietoina, sekä GML 3.0 muodossa vektoreina tai rastereina. Luokitteluun käytettävän aineiston laajuus ja tarkkuus riippuvat täysin kuvaluokittelun tuottavan palveluntarjoajan kriteereistä. Luokiteltu kuva tallennetaan polygoneina GML:ksi. Luokittelun tarkkuus tulee suhteuttaa työkoneen realistisiin toimintamahdollisuuksiin. 
Alueellinen tilannearvio antaa lohkokohtaista tietoa mm. tautiuhkista. Peltolohkorajojen naapuruusindeksointi yhdistettynä lohkojen kasvi- ja tautitietoihin omistajuudesta riippumatta mahdollistavat palvelun sujuvuuden. Palvelu voi olla joko aktiivinen tai passiivinen, ja tietosisältö on käsiteltävää peltolohkoa koskevaa attribuuttitietoa. Tietojen avulla voidaan $\mathrm{mm}$. valita torjunta-aineita ja ajoittaa toimenpiteen ajankohtaa. Yleiset olosuhteet keskittyvät kumulatiiviseen säähän, nykyiseen säähän, sekä sääennusteeseen. Näillä tiedoilla tarkennetaan lähinnä myös luotavan työtehtävän ajoitusta.

Työtehtävä luodaan, kun kaikki tarvittava tieto on saatavilla. Suunniteltu työtehtävä lähetetään palveluntarjoajalle GML-muodossa. Palveluntarjoaja tarkistaa automaattisesti työtehtävän määräystenmukaisuuden ja huomauttaa mahdollisista hyvien viljelykäytäntöjen poikkeamista. Palvelu palauttaa tiedon joko hyväksynnästä, tai tiedon siitä, mistdä säännöstä poiketaan. Hyväksytty työtehtävä ladataan työkoneen ISO 11783:n (ISOBUS) kaltaiseen tehtäväohjaimeen (TC). Työ voi alkaa, kun palvelimelta saatu säätieto on vaatimusten mukainen. Tehtäväohjain lataa WMS-palvelun (web Map Sevice) kautta sopivan taustakartan (kuva 3).

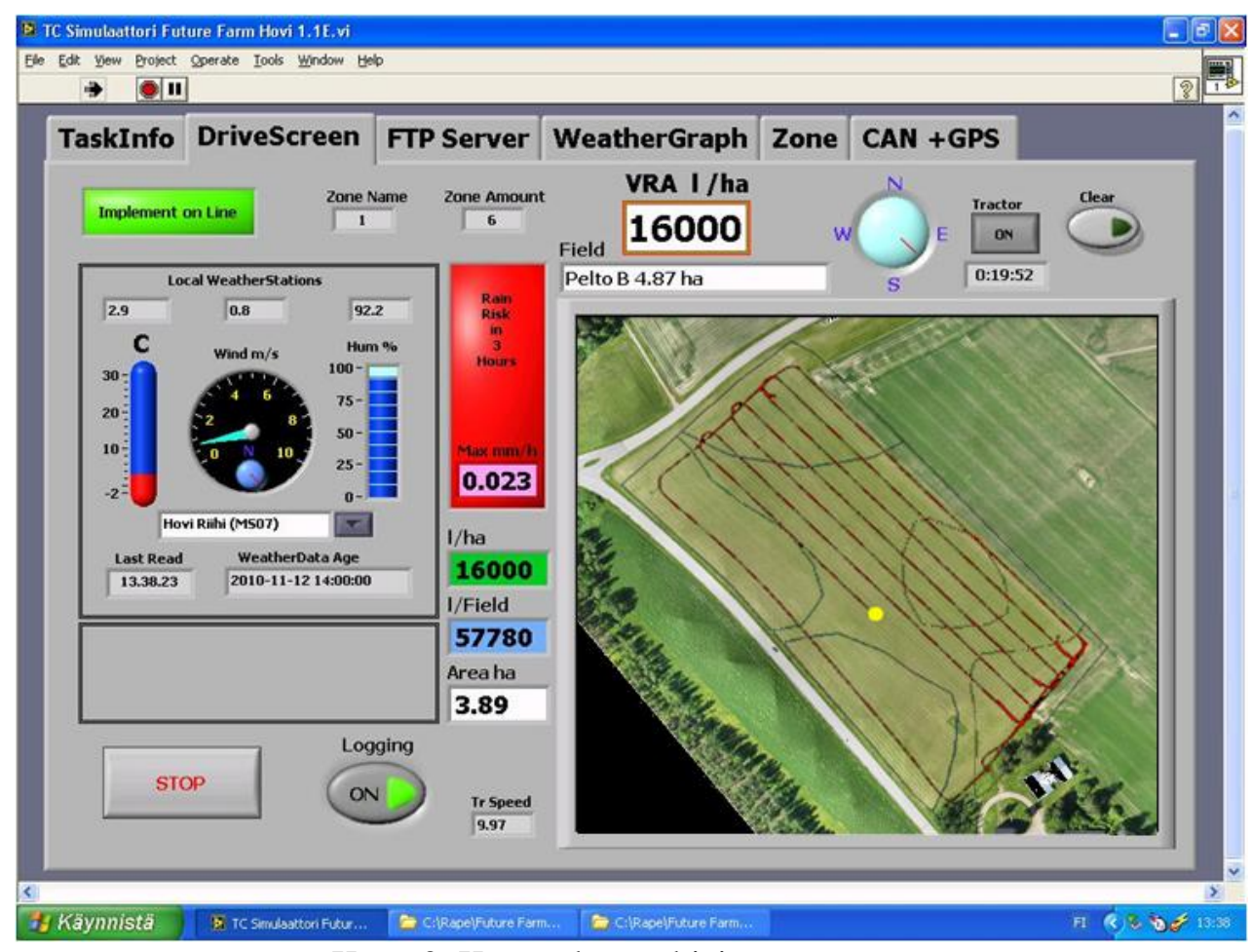

Kuva 3. Kuva tehtäväohjaimen näytöstä.

Työ joudutaan olosuhteiden muutoksen takia keskeyttämään (lannoite loppuu, ja jatketaan toisenlaisella lannoitusseoksella). Keskeytyneestä työstä lasketaan sen kattama alue, ja tämä lähetetään vektorimuodossa palveluntarjoajalle, joka vuorostaan laskee uuden työtehtävän muuttuneiden säätöarvojen ja jo toteutuneen työalan perusteella. Sekä tiedonsiirron että laskennan täytyy tapahtua muutaman minuutin aikana. Seuraavaksi Työkone jatkaa työtään uusien säätöarvojen mukaan. Työn loputtua kerätty data lähetetään kokonaisuudessaan palveluntarjoajalle, joka laskee yhdistellystä työstä tarkan toteutumakartan eri attribuuteille (kuva 4), sekä laskee lohkokohtaiset summatut tiedot. 


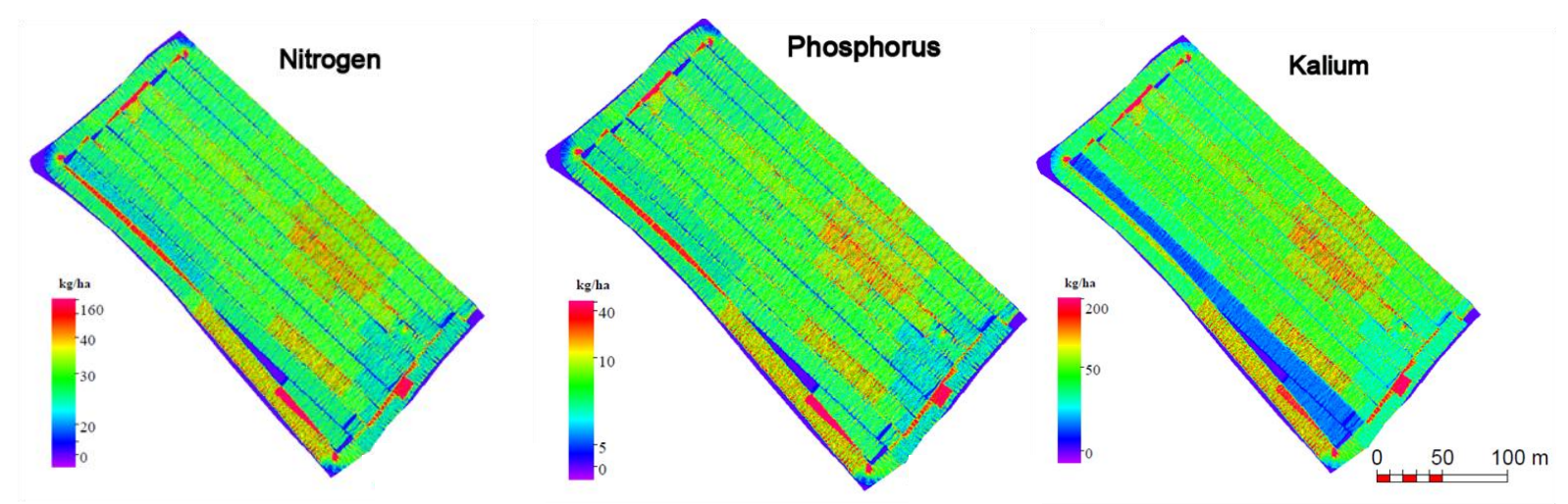

Kuva 4. Lannoituksessa levitetyn typen, fosforin sekä kaliumin levitysmäärät toteumakarttoina.

Lohkokohtaiset tiedot hyväksytetään vielä määräystenmukaisuuden tarkistavalla palveluntarjoajalla. Lopuksi hyväksytty työ siirtyy lohkokirjanpitoon, jossa se on osa viljelyn onnistumisen arviointiin käytettävää aineistoa. Toteumakarttaa voidaan hyödyntää mm. 1) arvioidaan kyseisen viljelytoimen onnistumista, 2) määritellään tarpeet lisätoimille, 3) luodaan uusia työtehtäviä, 4) arvioidaan viljelyprosessia kokonaisuudessaan, 5) vertaillaan eri peltolohkoja, sekä 6) määritellään uusia kehitysmahdollisuuksia ja vaatimuksia.

\section{Johtopäätökset}

Esitelty konsepti osoittaa, että web-pohjaisella puurakenteisella arkkitehtuurilla voidaan toteuttaa monipuolisia tulevaisuuden vaatimukset täyttäviä viljelytoimia. Näin mahdollistetaan useiden eri palveluntarjoajien hyödyntäminen samalla keventäen viljelijän työtaakkaa. Suunnitellun ja toteutuneen työn oikeellisuus saadaan osoitettua jäljitettävyyttä ja läpinäkyvyyttä varten. Parhaimmillaan aineistojen monipuolinen saatavuus ja rajapintojen yhtenevyys mahdollistavat tehokkaamman ja kokonaan uudenlaisen tietämyksentuottamisen koko viljelyprosessissa. Ongelmakohtina ovat kuitenkin eri prosessien automatisointi ja rajapintojen tarkka määrittäminen. Lisäksi geneerisyyden säilyttäminen eri tietojen ja tietolähteiden yhtenäistämisessä, erilaisten sääntöjen ja parhaiden käytäntöjen numeeristaminen, tiedon omistamisen ristiriidat, riippuvuus tietoliikenneyhteyksistä, sekä vastuun hajauttamisen tuomat ongelmat.

\section{Kirjallisuus}

Blackmore, S. \& Apostolidi, K., 2011. Future Farm Project Final Report:

http://www.futurefarm.eu/system/files/FFD8.9_Final_Report_4.1_Final.pdf ( 30.11.2011)

Nikkilä, R., Seilonen, I. \& Koskinen, K., 2010. Software architecture for farm management information systems in precision agriculture. Computers and Electronics in Agriculture. v70 i2. 328-336. 14

Pesonen, L., Ronkainen, A. \& Sørensen, C. 2011. Final report and documentation specification of FMIS, FutureFarm deliverable 3.7.: http://www.futurefarm.eu/system/files/FFD3.7_Final_Rep_Doc_Spec_Final_0.pdf $(30.11 .2011)$

Sørensen, C., Pesonen, L., Suomi, P., Fountas, S. \& Basso, B., 2009. Final Specification of Materal and Information Flow, FutureFarm deliverable 3.2.:

http://www.futurefarm.eu/system/files/FFD3.2_Specification_Of_Material_Final.pdf (30.11.2011)

Wiebensohn, J., Nikkilä, R., Oetzel, K. \& Kluger, S. 2011. Electronic knowledge management and transfer for agriculture. FutureFarm deliverable 4.6:

http://www.futurefarm.eu/system/files/FFD4.6_Electronic_knowledge_management_final.pdf 